CATALAN REVIEW

Catalan Review

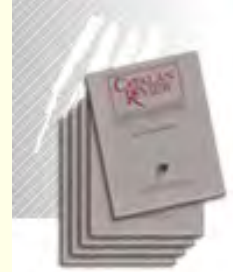

You are accessing the Digital Archive of the Catalan Review Journal.

By accessing and/or using this Digital Archive, you accept and agree to abide by the Terms and Conditions of Use available at http://www.nacs-

catalanstudies.org/catalan review.html

Catalan Review is the premier international scholarly journal devoted to all aspects of Catalan culture. By Catalan culture is understood all manifestations of intellectual and artistic life produced in the Catalan language or in the geographical areas where Catalan is spoken. Catalan Review has been in publication since 1986.
NORTH

AMERICAN

CATALAN

SOCIETY
Esteu accedint a l'Arxiu Digital del Catalan Review

A l' accedir i / o utilitzar aquest Arxiu Digital, vostè accepta i es compromet a complir els termes i condicions d'ús disponibles a http://www.nacs-

catalanstudies.org/catalan review.html

Catalan Review és la primera revista internacional dedicada a tots els aspectes de la cultura catalana. Per la cultura catalana s'entén totes les manifestacions de la vida intel lectual i artística produïda en llengua catalana o en les zones geogràfiques on es parla català. Catalan Review es publica des de 1986.

\title{
Theatrical Representations of St. Christopher throughout the Crown of Aragon during the Middle Ages Anthony J. Grubbs
}

Catalan Review, Vol. XX, (2006), p. 273-289 


\title{
THEATRICAL REPRESENTATIONS OF ST. CHRISTOPHER THROUGHOUT THE CROWN OF ARAGON DURING THE MIDDLE AGES
}

\author{
ANTHONY J. GRUBBS
}

\section{ABSTRACT}

As the patron of travelers, St. Christopher inspired one of the most popular cults to spread throughout medieval Europe. The Iberian Peninsula was no exception: his gigantic following spanned the region and his image adorned the walls of most churches and cathedrals. Manifestations were not limited to the plastic arts, however, and paratheatrical representations of St. Christopher were fairly common in processions celebrating Corpus Christi and other religious holidays, especially in Valencia, where the saint enjoyed even greater esteem. Furthermore, the mystery of his conversion and martyrdom was also staged during religious festivals during the fifteenth century. This essay traces the evolution of the hugely popular cult of St. Christopher in medieval Iberia by looking at various artistic (re)presentations of the converted Canaanite, paying special attention to the Valencian processions and two extant autos sacramentales - one written in Valencian and the other in Castilian.

\section{$\mathrm{T}_{\mathrm{h}}$} popularity during the Middle Ages due to his totemic and harmdeflecting powers. The saint was also highly regarded because he reflected many qualities esteemed at the time: the dedication to hard work in the name of God, steadfastness against the Devil, and possession of an organic, innate logic. As the saint of travelers and pilgrims, his immense appeal attracted an even greater number of worshippers as society became more mobile because of commerce, warfare, and religious pilgrimages. In the Iberian Peninsula St. Christopher's gigantic following spanned the region; in fact, relics of the saint can still be found in the cathedrals of Toledo, Valencia, Santiago de Compostela, and Astorga.

In addition to physical remains, artistic renderings of the saint, such as frescoes and paintings, adorn the walls of most Iberian churches, and others, in the form of statues and woodcarvings, often populate both religious and secular buildings, serving to protect the faithful. ${ }^{\mathrm{T}}$ The rendering of the saint was normally situated near an exit,

I Such statues were used not only used to honor Saint Christopher but also to convert non-Christians. According to legend, in June 9, 1391, in Toledo, a statue miraculously appeared in a synagogue during religious services, resulting in the conversion of 
a custom motivated by the belief that when devotees saw the giant's image nothing bad would befall them that day. The representation of St. Christopher was not limited to the plastic arts, however, and his life and death were commonly portrayed in processions celebrating Corpus Christi and other religious holidays. Furthermore, variations of his conversion and martyrdom were staged in both the religious and secular milieu between the fifteenth and eighteenth centuries in the Iberian Peninsula. The examination of some of these stagings of St. Christopher's conversion and martyrdom offers insight into the development of his cult of worship as well as reveals clues as to the evolution of religious theater and its effects on society. This essay specifically explores three dramatic works from the Crown of Aragon during the fifteenth century: one mystery play from Valencia and two consuetas from Mallorca, concentrating on their performative aspects and the public reception as they relate to the contemporary culture. Several recent critical approaches dealing with performance and the study of public reception inform this study, demonstrating new perspectives with regard to early Iberian theater. In the past, it has been the general trend of Hispanists studying early and early modern drama to perform close readings of the written text, concentrating on the inner workings of the plays as literature. Although these explications have proven revealing, they tended to downplay the fact that the theater was originally meant to be performed. It is, therefore, pertinent to underscore the integration of culture and theater as well as to recognize the connection among all of the participants of the dramatic spectacle-both on and off the stage.

St. Christopher's presence in Iberia has been a long one. Fernando Baños Vallejo asserts that the passionary of St. Christopher has been part of the Iberian oral tradition since the eighth century (42) and the first extant written text is the anonymous Passio Sancti Christophori et comitum, dating between the eleventh and thirteenth centuries. A quick glance at the abundance of hagiographic literature at the time suggests that the Muslim occupation of the Iberian Peninsula did not interfere with the production nor affect the popularity of hagiographic literature because of the Muslim's religious tolerance and the Christian's recuperation of land. The end of the twelfth century saw a rise in the popularity of martyrologies because of the common practice of the cofradias (lay brotherhoods) to adopt patron saints as well as the surge in cultural activity in some of the religious centers of the peninsula, including Toledo, Santiago de Compostela, and Santa Maria de Ripoll. Hagiographic literature also gained momentum in the

Gooo Jews and the transformation of the synagogue into a monastery. Sec Vol. 1 of the Sanctorum Julii (173i). 
thirteenth century with the release of Jacobus de Voragine's Legenda aurea (c.1260), the authoritative martyrology of the Middle Ages. Popularity and general readership dropped off in the fourteenth century due to numerous crises in Europe: wars-economic hardship, and the plague-but the fifteenth century was one of literary renovation and rebirth, especially in the Romance languages, which led to the frequent translation of Voragine's work. ${ }^{2}$ As a result of this newfound linguistic accessibility, St. Christopher became an even more popular figure in the Iberian Peninsula, appearing in the literary works of Aragon, Castile, and Portugal, to name a few.

The cult of St. Christopher was not, however, immune to criticism. For example, Erasmus's In Praise of Folly (IsI) denounced the saint because of the dubious nature of his canonization and his admirers as well as because before the fifteenth century, the process of beatification was not necessarily based on church edict but rather on popular approval. In general, the populace worshipped saints because of their supernatural abilities to perform miracles, displeasing the church, which claimed that these events should be considered divine acts. Not surprisingly, the uncertain roots and even pagan implications of many saints' martyrdom combined with the redirection of God's glory to their miracles drew the attention of the Inquisition.

In the mid-r5oos, the immense popularity of St. Christopher and other cults of worship spawned an attempt by the Catholic Church to suppress the worship of the cults due to the popular and fantastical nature of their canonization and deeds. As a result of the twenty-fifth session of the Council of Trent (December 3-4, 1563), the edict "On the Invocation, Veneration, and Relics of Saints and of Sacred Images" was released, a missive that reestablished the sovereignty of the Holy Trinity over any saint. The document stated that saints are mere conduits to God; therefore, it is inappropriate to worship them alone, which was idolatrous. This included the prohibition encompassed all types of representations: images, paintings, statues, and medals. Such icons, therefore, should serve only as a reminder of the power of God, and not a replacement. Though it is uncertain whether the Inquisition's attempt to control the popularity of the powerful cults of saints affected popular devotion, it most assuredly had other ramifications as to the diffusion of the legends. While not specifically targeting St. Christopher, the story of his martyrdom was most definitely hindered, at least in the commercial theater. In fact, very few playwrights - and none of the "canonical" dramatic poets-adapted the legend to the stage. Furthermore, there are only two extant comedias dealing with St. Christopher, and a third was censored in 
1643, causing riots in the streets of Seville. Of course, such reactions by both the church and the populace illustrate how the popularity of the cult had grown to monumental proportions.

During the Middle Ages religious theater proved an effective medium to disseminate religious dogma because it served as a model of conduct that was presented in an entertaining manner and appealed to a wide audience because of the universal and local appeal of the works. The birth of the mystery play emerged from an evolution of thematic and performative characteristics that were affected by both religious and profane factors during the Middle Ages. Many suggest that religious theater arose out of the necessity to reach a larger audience. Baños Vallejo notes that early on, the church recognized the need to simplify their teachings, leading to the vulgarization of the sermon in both linguistic and thematic terms; hagiographical stories, for example, served to break up the monotony of a sermon (100). Starting in the ninth and tenth centuries, when the church realized that it was important reach out to its followers, religious theater began to emerge from the dramatic aspect of the liturgy, especially during Christmas and Easter services. Similarly, Josep Romeu Figueras points to the profanization of religious theater, citing the use of secular actors, popular language, and local sources of inspiration-and I would add the public, since it is their understanding that would define the workas factors that transformed the dramatic genre, eventually leading to the mystery plays being written in Romance languages starting in the thirteenth century $(7-8)$.

Religious theater was popular in the Crown of Aragon, especially in Valencia, where the beginnings of a strong dramatic tradition were in place.To date, three Valencian mystery plays survive: Lo misteri de Sant Christòfol, Lo misteri de Adam y Eva, and Lo misteri de Herodes. In fact, these works were regularly performed and extremely popular until the nineteenth century, when their popularity dwindled as a result of the changing taste of the public (Ruiz de Lihory 99). The mystery plays were inspired by the Bible, apocryphal gospels, and both local and general traditions and legends, especially the Legenda aurea (Corbató 94). While the dramatic style was also popular in the rest of Europe, the Levantine versions of the plays distinguished themselves by being more dignified, omitting humorous situations and unnecessary characters, attributes more common to the works of England and France. Written in the regional language, these plays promoted regional spirit and identiry. The performance space changed as the plays were first performed in cathedrals and parish churches, and then later during the processions that celebrated religious festivals.

The religious procession formed part of paratheatrical tradition in Europe throughout the Middle Ages. Processions celebrating Corpus 
Christi started in Barcelona between the years 1319-2, but they did not appear in Valencia not until 1355. Descriptions of the processions have been discovered that date as early as $1407,{ }^{3}$ and most make special reference to the entremesas, referring to the carroza or roca, ${ }^{4}$ which were the ornate carts - similar to the modern-day float-that carried likenesses of various religious figures. At first the actors did not move or speak, but were simply "living" statues (Romeu 32).5 The representations did evolve, however, and in 1415 action was introduced and the figures began voicing a few words. Eventually they moved off the floats and performed the actual plays (Corbató, Misterios 165). Romeu makes reference to an extant document that details the 1624 Corpus procession in Barcelona, mentioning that the order of the procession was dictated by the cyclical, chronological conception of religion common at the time: starting with the creation of the world, next come the saints who are followed by the martyrs, with all the scenes represented on the floats (8).

Clearly, the spatial limitations offered by performing either on the float or behind it forced the playwright and the actors to adapt the works to the particular circumstances. This adaptation points to the evolution and the importance of performance, both on stage and on the street, in the procession.

Although a popular figure throughout the Iberian Peninsula, St. Christopher was especially esteemed in Valencia. Mérimée suggests that such affinity could result from a local legend that the saint's body parts were transported to Valencia in 828 , after having been removed from the cathedral in Toledo, but he is quick to note that this cannot be confirmed (46). I would suggest that the overall adoration more likely sprang up from Valencia being a seaport, where the presence of so many sailors and travelers would make St. Christopher an obvious choice for a patron. Furthermore, theatrical depictions of St. Christopher's life were regularly represented between the fifteenth and nineteenth centuries (Corbató 167). ${ }^{6}$

Vicente Boix dates Lo misteri de Sant Christòfol as early as 1449 (qtd. in Mérimée 38) but, by looking at the language, Corbató, among others (Ruiz de Lihory, Romeu, Milá), refutes the claim, situating three mystery plays during the last third of the fifteenth to the beginning of

3 Romeu indicates that the work is mentioned being performed in documents dating 1407, 1408, 1444, and 1453 (32-34).

${ }_{4}$ The term has been confused in the past with the short one-act interlude.

5. Music was soon added to the processions, the first documented example is in 1414 , but the procession was to honor a member of the royal family and not for Corpus Christi (Romeu 32).

6 See Ruiz de Lihory, who that this was due to lack of interest by the public. 
the sixteenth centuries ( 133$), 7$ though he strongly contends that they could have existed and possibly been performed in another form in the Cathedral of Valencia, where plays were represented before appearing in the processions. It is known that up until 1444 some mystery plays were performed in the cathedrals before exiting onto the streets, a practice stopped as a time-saving measure; Corbató supposes that St. Christopher was among them $(133-36){ }^{8}$ Though the exact date of the first mystery play dealing with St. Christopher will most likely always elude us, clear evidence exists that reveals his popularity in medieval and renaissance Valencia. Documentation relating to the entremesos (cast of actors) representing Jesus Christ and St. Christopher and costuming in the Corpus processions is found from I449, I451, and I517; the names of the carrozas are mentioned in 1517- St. Christopher was always on the Roca de Paradiss Terrenal (Romeu 35). Milá mentions in Orígenes del teatro catalán a $153 \mathrm{I}$ document that describes the representation of the play, which took place on foot behind the raca; his carroza is also mentioned in 1547 and 1583 (Corbató, Misterios 138-40); Romeu supports the idea that St. Christopher was a popular figure beforehand, appearing much earlier than is documented (38). Corbató gives an extensive list of documents mentioning St. Christopher in Misterios 138-40, which include orders, bills, and receipts for costumes, actors' salaries and scenery construction, in addition to descriptions of the order of the rocas of the processions.

The compact Lo misteri de Sant Christòfol starts in medias res and relates the Canaanite's encounter with a hermit, several pilgrims, and Jesus Christ. Such an abrupt beginning and end clearly illustrates the playwright's confidence in his public's knowledge of the legend and the play was clearly adapted from Voragine's work. It does diverge, however, from the Legenda aurea with its introduction of pilgrims, who arrive at the river bank and seek protection during their journey and, of course, a way to ford the river. Their presence does impart incongruities to the play since they announce their arrival with a song praising St. Christopher even though he has not yet been converted; both Romeu and Corbató have been quick to point out this inconsistency. Corbató concludes that they were added later, quite possibly by someone who took the most dramatic parts of other,

7 Romeu notes that the three extant mystery plays were copied in 1672 from an earlier version, now lost, by a cantor and minstrel named Josep Gomar. The version conserved in the Municipal Library of Valencia served, just like the primitive text, as a guide for the minstrels in charge of the sacred Corpus festivities. It seems that it was the poor state of the previous copy that dictated the need for a newer version.

8 All information is lost though some clues may be found in the Breviario Va- 
more extensive plays and compiled them into one (Corbató 43). Other shortcomings of the play include poor rhyme and meter, repetition of words, lack of dramatic action, and careless mistakes attributed to the copyist (Romeu 4I). He also questions the literary value of the work.

I argue that while these anomalies and shortcomings do indeed affect the actual written text of the play, it is for numerous reasons imprudent to discount completely the value of the work, primarily because the play offers us entry into the religious psyche of the times. We see in very few lines how the Canaanite giant, Reprobus, is converted from an obstinate and violent brute to a faithful and penitent servant of God, a clear reference to the moral superiority of the Christians. Furthermore, the performance of the work must also be considered since the play's ultimate purpose was to dramatize a religious lesson while entertaining the public. By taking other considerations into account, therefore, the validity and importance of the purportedly inferior work become apparent.

The mystery play is a short dramatic form that utilizes familiar stories and the impact of performance to underline the allegorical message. This play excludes superfluous details, counting on the public's a priori familiarity with the story, and concentrates on the actions and events that will most effectively affect the public. Although the play's beginning in medias res may seem to suggest that it was a fragment of a larger work, this is not necessarily the case; what it does prove is that the work was familiar to most, so there was no need to include background details. This illustrates how performance and reception affect the entire dramatic process, that is, the composition, representation, and reception of the work.

The characters are not developed to a great degree because, once again, they are familiar and recognizable. The giant, for example, fulfills the expectations of the public as a brutish but willing convert to Christianity. He is hesitant to fast as penitence but willing to undertake physical labor, highlighting the humanity of his character:
De dejunar, sert, no porré, perquè és mol gram ma presènsia.
Dau-me altra penitènsia, pare, y yo la cumpliré. (26)

The pilgrims, too, are familiar because they experience fear and worry about their journey and then show delight when it is clear that they will be able to ford the allegorical river of life with the help of St. Christopher and their faith. The hermit provides guidance and wise advice, and Jesus explains his providence over the world and performs a miracle. This economy of character development does not confu- 
se the public and it highlights the importance of the action of the play.

The laudatory song dedicated to St. Christopher has been seen as awkward by earlier critics, but I contend that it is appropriate and beneficial to the work. I disagree with the notion that it was carelessly intercalated. In fact, this song proves to be a valuable tool that facilitates the dissemination of the message of the play. The timely arrival of the pilgrims and the song praising St. Christopher reinforce the importance of his newfound vocation:

\author{
Puix de Déu tant alcansau \\ sant Christòfol gloriós, \\ feu-nos mersè que'ms vullau \\ en est riu dar-nos socors. (27-28)
}

The song emphasizes the majesty of the saint and his deeds, and should be considered outside of the dramatic context of the play. As the ultimate goal of the mystery play is to teach and entertain, the message conveyed by the song to the public actually reminds them what they are seeing. So the song was really a tool to underpin the message of St. Christopher's grandeur in a pleasant manner; its lack of chronology is not an issue.

The end of the play is as abrupt as the beginning but interestingly, it is highlighted by another song, this time sung in Castilian. The song is introduced by stage directions that read "Ara canten tots junts, en tonada a consert a quatre veus, les comples que es seguixen." The song is sung by the whole cast ("Tots junts") and gives advice regarding pilgrimages and pilgrims:

A estos pobres romeros
que van a Jerusalem
mándeles hacer bien.
Mándeles dar caridad
para pasar su camino.
porque pobre peregrino
pasa gran nesisidad.
La gente con piedad,
que van a Jerusalem,
mándeles hazer bien.

The use of Castilian may seem out of place but actually the contrary is true. Corbató, for example, mentions that the use of Spanish could be expected due to the large numbers of travelers who would have been in Valencia (99). In fact, the Castilian lyrics would have been understood by most. Mérimée suggests that the Castilian influence on stage and culture accounts for the language change (38-43). 
Besides these astute observations, I propose that the song serves two purposes. First, it enhances the universal nature of pilgrimage and the bilingualism of the play reinforces the notion that people from all areas are pilgrims. Second, the song, which seems to foresee the fin de fiesta or baile especially popular on the seventeenth-century secular stage, serves to end the spectacle on a high note.

The work is short but its message is explicit. The piece is ultimately didactic but entertaining additions make the message more palatable and comprehensible since it is materialized on stage, using various dramatic techniques.

Finally, it seems clear that the performance of the text is a preoccupation as the stage directions are included in the 1672 copy (made from an earlier version) and while we cannot know for sure whether they were present in the earlier version, it is clear that they were included to guide whoever was in charge of directing the play for the Corpus celebration. Clearly, by looking at other, extratextual elements of the play, we gain further understanding of its performance and the culture.

The two Mallorcan works, Consueta de la conversió de Sant Cristòfor (26I verses) and Consueta de la passió de Sant Cristòfor (437 verses), were not performed in processions but rather in churches. They are unified by similar style, meter, and technique and combine to tell a more detailed version of the St. Christopher legend. Corbató suggests that they were taken from inspired by the Valencian auto (I36), a notion rejected by José Amícola (I). Both plays reveal scenic complexity and dynamic action as they offer a comprehensive vision of St. Christopher's conversion and martyrdom. It is clear that the Legenda aurea inspired the works even though the second play diverges from Voragine's work. The two-part division of hagiographic dramas was common: the first part would commonly recount the conversion of the saint and the second his martyrdom. Romeu, however, suggests that the division of the two plays is due to the need for different scenery on stage (145). They both stand out because of the clearly stated stage directions, which were not common in any theatrical works at the time. These aspects as well as others illustrate how the two plays give us greater entry into the playwriting process and the performance of the play.

The first consueta takes advantage of fast-paced dramatic action and movement, making the play more dynamic and its message more convincing. It boasts expressive narration of important events and by underlining the action, the legend is brought to life by the inclusion of key episodes taken from Voragine's version.

The play also includes a prologue-added later, according to Romeu, noting its inferior quality and more modern rhyme scheme 
$(\mathrm{I} 48)^{9}$ - confirming the cognizance of the playwright of the intricacies of the dramatic process. In the prologue, the Auctor attempts to settle the audience members by praising their virtues and explaining the plot and the message of the play. He warns them to pay attention to ensure their salvation:

\author{
Vellau ab atenció, \\ guardau-vos de descuydar, \\ que vostra salvatió \\ ab mold gran atenció \\ l'aveu tots de percurar. (67)
}

The inclusion of the prologue underlines the notion that the dramatic works are meant to be performed for an audience. Likewise, the information provided in the prologue is one method to ensure that the message is understood by all.

The consueta details the course of St. Christopher's conversion, which develops the characterization of the protagonist. His faith undergoes a transformation, because at first he simply wants to serve the greatest, most powerful master in the world and his allegiances are brittle. Tension mounts in the play in conjunction with the giant's frustration as he finds faults in all of his masters, until he meets the hermit and then Jesus Christ. A feeling of conflict continues to grow when, while speaking to the hermit as how he can serve God, the Canaanite refuses to fast and reveals that he does not know how to pray. Christopher's brutish demeanor softens as the play progresses and he becomes a more eloquent speaker who is determined to preach his faith after his conversion to Christianity-one could say that he moves from being a gentile to a gentle giant. After his conversion he proclaims:

\footnotetext{
Gràtias grans vos fas, Senyor, que t'ets mostrat a mi peccador, y en per tostemps siau loat, puis a mi vos sou demostrat

Gran miracle Déu à obrat avent él lo bastó fullat; e dón-vos tot lo món onor puis que sou vós ten gran senyor. Vaig-me'n cert a predicar an els gintils, sens més terat,
}

9 Romeu points out that the poet used traditional rhyme schemes in the quatrains: aabb, abab, abba, which were typical of old Catalan, but the prologue uses a more modern rhyme scheme, abaab, and the stanzas are made up of 5 verses (I48). 
que's convertesquen a Déu, puis axò̀s lo manar seu. $(81-82)$

The dedication he shows towards God strongly contrasts his fickle nature before conversion, which emphasizes the total devotion to the religious faith.

As in the Valencian play, music plays an important role in the performance. Song serves numerous purposes in the play: it progresses the storyline, describes emotions, introduces characters, and develops the character for the public. The protagonist frequently sings the Alma laudes (Eulailiae Hymn), underlining his religious devotion. The Christe qui luxe is also sung by the first king. News of the Devil is sung by a joglar, striking fear in the second king and causing the departure of the giant. As the giant abandons the service of the second king, two porters sing a duet that serves as the narrative voice and advises the king not to weep over the loss of his vassal, a phenomenon similar to the classical Greek chorus. All of the music and song combines religious with secular traditions and complements the story.

The dramatic action of the play suggests complex scenery. For example, the protagonist serves four masters (two kings, the Devil, and Jesus Christ) and speaks to the hermit, implying much movement. Based on his examination of the original manuscripts, Romeu suggests a complex bi-level stage. 10 A sun tops the scene, with the throne of the first king off to one side, the throne of the other towards the middle of the stage, next to that is the hermitage, and off to the other side would be the giant's shack and the river (I46). He admits that this is only a hypothesis and continues by discussing some of the problems staging the miracles. In recognizing the complexity of the production it becomes clear how the stage, too, would have affected the public's reception of the play and interpretation of the myth. Moreover, performance and public reception were obvious preoccupations of the actors since the stage directions were included in the manuscript, which seems logical since the play was repeated yearly, presumably by different people.

The second consueta, which recounts the passion and martyrdom of St. Christopher, is more intimate than its counterpart and diverges from the storyline of the Legenda aurea. Like the other works, this play also falls under the sharp eye of critics: Romeu asserts that its literary value is minimal and the style is forced and depersonalized but he does mention its strengths, which lie in the dynamic aspect of the story (I53). Indeed, this isa very important characteristic since the staging of the

10 See William Hutchinson Shoemaker's The Multiple Stage in Spain during the Fifteenth and Sixteenth Centuries. 
work would have served to impress the public and reinforce their belief in St. Christopher. Also similar to the other consueta, stage directions guide players in their actions and emotions, clearly underlining the recognition of the importance of performance. The movement and action detailed in the script also suggest complex scenery in the performance space.

It is the dramatic action that highlights this play, and its performance added impact because of its varied and graphic nature. In all of the plays, Christopher is a very charismatic figure, but in this play his sway over others is even greater. He converts everyone he meets and the scenes of conversion are distinct and increasingly more dramatic. The giant converts 400 knights with the flowering staff, the same miracle that Jesus performed in the first play. This scene differs from that of Voragine's work where he converts simple townspeople; the use of knights, therefore, highlights the importance of the saint's message and their presence on stage would impress the public. He also converts two courtesans who are sent to tempt the incarcerated giant, simply with his pious and holy gaze. The stage directions state that they enter his cell as he prays to God:

SANT CHRISTOFOL. O senyor, per te gran bondat

jo's prech ma guardau de peccat,

perquè sempre puga servir

a vós, Senyor, fins el morir

PRIMERA DONZella. Ages de nós compasió

y dol-ta de nòstron treball.

¿Tu no sents gens nostro gran mal

que tenim naltros en lo cor?

SEGONA DONZELLA. Fes a la tua voluntat, que res te fóra desnegat. (99)

The women are moved and plead to St. Christopher that he make them believe in Christianity so that they may be forgiven their sins, and he complies:

SANT CHRISTOFOL. de Deú sou illuminades,

del lum de la veritat;

puis que stàveu obsegades,

a-vos tretas de peccat.

LAS DUAS DONZELLAS. (agenollades). Senyor, gràtias vos fem

del lum que trobat avem.

Senyor, perdó vos demanam,

feu que de vós lo elcansem. (roo-or)

Finally, St. Christopher converts the king, when the latter's blindness is cured by the healing powers of the blood spilling from the 
saint's head after being decapitated. The king praises God's almighty powers:

\author{
O valgue'm Déu, y quan potent \\ c'és el Déu dels cristians! \\ Betetgem-nos tots, mos germans, \\ fent gràtias a l'Omnipotent. (113)
}

He continues praising the piety and greatness of St. Christopher. Clearly, the saint's constancy and martyrdom are inspiring at the end of the play, and he "represents fortitude and the triumph of virtue" according to David Viera (86). A song sung by the remaining cast members follows this last conversion. The lyrics reiterate the exclamations of the king and the overall message of the play with regard to the importance of piety and faith. Moreover, as in the Valencian mystery play, the song serves to end the play on a more pleasant note. Finally, the Auctor takes the stage once again to close the play with a short epilogue. He begs the pardon of the audience for any errors in the text and for any offense taken from the performance. $\mathrm{He}$ also assures them that the holy message was not intended to insult but to instruct. The epilogue, of course, offers another clear indication of the author's cognizance of the performative aspects of the play, his lesson was transmitted by shocking means, which were necessary not only to explain but also to entertain.

In addition to the conversion scenes, the performance is highlighted by others just as graphic and emotive. For example, the two defiant courtesans defile a statue of Jupiter, pulling it down to the ground and cursing it, for which they are executed. The martyrdom of St. Christopher is long and bloody. He is whipped and then crucified on a tree while wearing a burning hot steel helmet. Some knights then attempt to shoot the giant with arrows but the missiles are deflected from him and one blinds the king, and the martyr is finally decapitated. The parallels between Jesus Christ and St. Christopher are unmistakable, and they include the similarity of their names, their passions and martyrdoms, all of which are underscored by the obvious Eucharistic symbolism seen in the play. These parallels would not have been lost on the public, whose beliefs would have been strengthened with such a dramatic chain of events, leaving no doubt-either verbally or visually - as to the message of the primacy of God.

Without a doubt, religious theater had an enormous impact on medieval society. Theater was an institution that appealed to all people, regardless of class, since the entire public was the target of the message. In "Profession or Performance? Religion in Early Modern Literary Study," Kate Narveson notes that religion involves cultural phenomena in which the sacred functions as a structuring principle and that the 
early modern culture was religious and, therefore, informed by the structuring principle of the divine (I4). Although in her study she refers to medieval England, the same holds true in the Iberian Peninsula. Theater becomes a dramatic appropriation of religious texts that result in performed representation of dogmatic teachings. Consequently, the message is made more accessible precisely because of the performance, whose reception is multidimensional as mediation and meditation of the theme and belief are required by the spectacle. According to Eli Rozik, a dramatic world is created and it serves as a metaphor for the real world of the spectator and it is this relationship that explains the total involvement of the spectator with the work despite the gap between fictional and real worlds. It is this difference that actually forms association and meaning (277). The religious theatrical text, therefore, ultimately describes the world of the spectators in a metaphorical manner, one that is relatable to their experience. The work serves as an example of conduct. The spectacular staging and dynamic action materializes the message for the public so that it is more comprehensible. Religious theater was effective and delivered a dogmatic message precisely because of its performance, making it more tangible than a sermon, for example.

Clearly, performance proves integral to a full understanding of the dramatic spectacle, its elaborate scenery and impressive characters. In the case of the three religious plays, the performative aspects of St. Christopher's life are also important in conveying a religious message and they make the work more accessible to the public. The mystery play is first and foremost a religious play that utilizes performance to produce a sacred message that is comprehensible to the congregants, and both the church and the playwright must have understood the importance of entertainment in this genre of theatrical drama. Indeed, the legend of St. Christopher was well known and well loved at the time of the representation and, in this case, it served as a vehicle to transmit the dogmatic message of the power of Jesus Christ. We are then reminded that when examining the playwriting process, it is important to consider the influence of the potential receivers of the (performed) text, as well as the various phases that it goes through before being staged. Clearly, reception is planted deeply in the mind of the playwright, not only for didactic reasons but also for its entertainment value.

Though the degrees of dramatization and characterization vary in the plays, they do, nonetheless, illustrate the importance of St. Christopher in early modern culture in the Catalan-speaking lands, by demonstrating his majesty, devotion, and charisma, and all the while promoting the religious dogma imposed by the church at the time. By placing performance and reception on an even plane with the written 
text, we see even more clearly how the quotidian culture influences the playwriting process and the dramatic spectacle as a whole, infusing previously lost-or overlooked-literary and cultural values into the plays, which remained virtually unchanged for hundreds of years.

\section{ANTHONY J. GRUBBS MICHIGAN STATE UNIVERSITY}

\section{WORKS CITED}

AINAUD DE LASARTE, Juan, "Superviviencias del passionario hispánico en Cataluña." Analecta sacra Tarraconensia; revista de ciencias histórico-eclesiásticas. 28 (1955): II-24.

AMíCOLA, Joste. "El Manuscrito Llabrés y el teatro castellano del siglo XVI." Actas IV de la Asociación Internacional de Hispanistas. 1971. 2I Jan. $2007<$ http://cvc.cervantes.es/obref/aih/pdf/o4/aih_ 04_I_oIs.pdf>.

Auto de Sanct Christoval. Autos, farsas y coloquios del siglo XVI. Ed. L. ROUANET, 4 vols. New York: Verlag, 1979. 450-66.

BAÑos VALLEJo, Fernando. La hagiografía como género literario en la edad media. Oviedo: Departamento de Filología Española, 1989.

Baños Vallejo, Fernando, and Isabel Urfa MaQua. La leyenda de los Santos ( Flos Sanctorum " del ms. \& de la Biblioteca de Menéndez Pelayo). Santander: Sociedad Menéndez Pelayo, 2000.

BuSSELL THOMPSON, Billy, and John K. WALSH. "Old Spanish Manuscripts of Prose Lives of the Saints and their Affiliations. I: Compilation A (The Gran Flos Sanctorum)." La corónica I5.I (198687): $17-28$.

Consueta del gloriós Sant Christòfol. Teatre Hagiogràfic. Ed. Josep ROMEU FigUeras. 4 vols. (Vol. 3 ) Barcelona: Barcino, 1957. 65-82.

Consueta del martiri de Sant Christòfol. Teatre Hagiogràfic. Ed. Josep ROMEU FigUERAS. 4 vols. (Vol. 3 ) Barcelona: Barcino, 1957. 83-II5.

Corbató, Hermengildo. Los Misterios del corpus de Valencia. Berkeley: U of California P, 1932.

- "Notas sobre el misterio de Elche y otros dramas sagrados de Valencia." Hispania I5.2 (1932): 103-08.

-. "Some Outstanding and Recurring Themes in Valencian Literature," Hispania 14.3 (1931): 167-82.

COURCELLES, Dominique de. L'ecriture dans le pensée de la mort en Catalogne. Paris: Ecole de Chartres, 1992.

DEYERMOND, Alan. "Lost Hagiography in Medieval Spain." Saints 
and their Authors: Studies in Medieval Hispanic Hagiography in Honor of John K. Walsh. Ed. Alan Deyermond et al. Madison, WI: Hispanic Seminary of Medieval Studies, 1990. 139-48.

DiaZ-PLAJA, Guillermo. "Una aportación al estudio de la técnica escénica medieval." Estudios escénicos; Cuadernos del Instituto del Teatro. I (1957): 9-25.

HEAD, Thomas. Medieval Hagiography. London: Garland, 2000.

LlABRÉS I QUINTANA, Gabriel. "Repertorio de consuetas representadas en las iglesias de Mallorca (siglos XV y XVI)." Revista de archivos, bibliotecas y museos 5 (I901): 920-27.

Mérimée, Henri. El arte dramático en Valencia. 2 vol. Trans. Octavio Pellissa Safont. Valencia: Institució Alfons el Magnànim, 1985.

Milá y FontAnals, Manuel. Origenes del teatro catalán. Obras completas del Doctor D. Manuel Milá y Fontanals. Ed. Marcelino MENÉNDEZ Y PELAYO. 6 vols. (Vol. 6). Barcelona: Verdaguer, I895. Misteri de Sant Christòfol. In Teatre Hagiogràfic. Ed. Josep ROMEU FIgueras. 4 vols. (Vol. 3) Barcelona: Barcino, 1957. 25-33.

MonRoy y Silva, Cristóbal. El gigante cananeo, San Cristóbal. Seville: Padrino, c. 1700.

Narveson, Kate. "Profession or Performance? Religion in Early Modern Literary Study." In Fault Lines and Controversies in the Study of Seventeenth-Century English Literature. Eds. Claude J. and TedLarry PEBWORTH. Columbia, MO: U of Missouri P, 2002. I11-29.

Newall, Venetia. "The Dog-Headed St. Christopher." Folklore on Two Continents: Essays in Honor of Linda Degh (1980): 242-49.

Obra a llaors de Sent Cristofol. Valencia: Pere Trincher, 1498.

ORTI, Jacinto. Historia del hallazgo de la imagen de S. Christoval, sus milagros, y fundación del real convento de religiosas canongesas agustinas en la ciudad de Valencia. Valencia: Cosme Granja, 1740.

RomEU Figueras, Josep. Introduction. Teatre Hagiogràfic. Ed. Josep ROMEU FIgUERAS. 4 vols. (Vol. i) Barcelona: Barcino, 1957. 6-12.

- Introduction. Consueta de la conversió de Sant Cristófor. Teatre Hagiogràfic. Ed. Josep Romeu Figueras. 4 vols. (Vol. 2) 145-49. Barcelona: Barcino, 1957.

- Introduction. Consueta de la passió de Sant Cristòfor. Teatre Hagiogràfic. Ed. Josep Romeu FIgUERAS. 4 vols. (Vol. 2) 150-53. Barcelona: Barcino, 1957.

- Introduction. El misteri valencià de Sant Cristòfor. Teatre Hagiogräfic. Ed. Josep RomeU Figueras, 4 vols. (Vol. 2) 32-44. Barcelona: Barcino, 1957.

RossicH, Albert, ed. El teatre català dels origens al segle XVIII. Actes del II Col-loqui Problemesi Mètodes de Literatura Catalana Antiga: «Teatre català antic». Girona, 6 al 9 de julio 1998. Kassel: Reichenberger, 2001 . 
ROUANET, L., ed. Autos, farsas y coloquios del siglo XVI. 4 vols. New York: Verlag, 1979. 203-05.

RozIK, Eli. "Theatrical Experience as Metaphor." Semiotica I49 (2004): $277-96$.

Ruiz dE Lihory, José (EI Barón de Alcahalí). La música en Valencia: diccionario biográfico y crítico. Valencia: Domenech, 1903.

SÁNCHEZ-ARJONA, José. El teatro en Sevilla en los siglos XVI y XVII. Madrid: Alonso, 1887.

- Noticias referentes a los anales del teatro en Sevilla desde Lope de Rueda hasta fines del siglo XVII. Seville: Rasco, 1898.

SHOEMAKER, William H. The Multiple Stage in Spain during the Fifteenth and Sixteenth Centuries. Westport, CT: Greenwood, 1973.

URIA MAQUA, Isabel. "Relatos hagiográficos en prosa romance (Ms. 8 de la Biblioteca Menéndez Pelayo)." Medioevo y literatura. Actas del $V$ Congreso de la Asociación Hispánica de Literatura Medieval, IV. Ed. Juan PAREDES. Granada: U of Granada P, 1995. 4I5-42I.

VIERA, David. Medieval Catalan Literature: Prose and Drama. Boston: Twayne, 1988.

VORÁGINE, Jacobus de. The Golden Legend. Trans. Granger Ryan and Helmut Ripperger. London: Longmans, Green and Co., 194r. 